\title{
NON-CARCASS COMPONENTS OF CATTLE FINISHED IN FEEDLOT WITH HIGH GRAIN DIET
}

\author{
COMPONENTES NÃO INTEGRANTES DA CARCAÇA DE BOVINOS TERMINADOS \\ EM CONFINAMENTO COM DIETA DE ALTO GRÃO
}

\author{
Jonatas CATTELAM ${ }^{1}$; Flânia Mônego ARGENTA ${ }^{2}$; Dari Celestino ALVES FILHO ${ }^{3}$; \\ Ivan Luiz BRONDANI ${ }^{3}$; Diego Soares MACHADO ${ }^{4}$; Lucas Braido PEREIRA ${ }^{4}$; \\ Gilmar dos Santos CARDOSO ${ }^{4}$; Marcelo Ascoli da SILVA ${ }^{5}$; Sander Martinho ADAMS ${ }^{5}$; \\ Alexandra Fabielle Pereira VIANA ${ }^{5}$; Mauren Burin da SILVA ${ }^{5}$; Camille Carijo DOMINGUES \\ 1. Dr., Universidade Federal da Fronteira Sul - UFFS, Realeza, PR, Brasil. jonatas.cattelam@uffs.edu.br; 2. Dr., Sociedade Educacional \\ Três de Maio - SETREM, Três de Maio, RS, Brasil; 3 Dr., Universidade Federal de Santa Maria - UFSM, Santa Maria, RS, Brasil; 4. \\ MSc. em Zootecnia, Discentes PPGZ - UFSM, Santa Maria, RS, Brasil; Bolsista CAPES; 5. Zootecnista, Discente PPGZ - UFSM, Santa \\ Maria, RS, Brasil, Bolsista CAPES.
}

\begin{abstract}
The objective of this study was to quantify the non-carcass components of steers and heifers finished in feedlot and fed with high grain diets. Altogether, 45 Charolais and Nellore crossbred cattle of two categories, 21 heifers with an initial age of 32 months and 24 steers with an initial age of 20 months, were used. The animals were fed with diets of $100 \%$ concentrate and divided in groups according to the energy source used in the form of rice, white oat, or corn; each diet group had seven heifers and eight steers. The experimental design was completely randomized with a factorial $3 \times 2$ arrangement, using $\mathrm{P}<0.05$. The slaughter weight and empty body weight were higher in animals fed with corn (430.4 and $379.1 \mathrm{~kg}$, respectively) or white oat (449.3 and $378.0 \mathrm{~kg}$, respectively) as compared to animals fed with rice (401.9 and $341.0 \mathrm{~kg}$, respectively). With the exception of heart and abomasum fat, all other adipose tissue deposits were lower in animals fed with rice. The steers showed higher development of internal organs $(3.67 \%$ versus $3.24 \%)$, feet $(2.33 \%$ versus $2.06 \%)$, and total peripheral components $(15.9 \%$ versus $15.1 \%)$, while heifers presented higher total fat deposition $(6.45 \%$ versus $5.75 \%$ ), as expressed in relation to empty body weight. Thus, the use of high grain diets based on corn or white oat in the finishing of cattle leads to higher development of internal organs and digestive tract, while feed with rice grain provides less deposition of adipose tissue.
\end{abstract}

KEYWORDS: Corn. Digestive tract. Empty body weight. Fat. Rice. White oat

\section{INTRODUCTION}

The use of feedlot is a widespread practice among beef cattle producers. A growth of $61.7 \%$ has been observed in the domestic livestock over last 5 years, and this finishing system contributes to approximately $11 \%$ of the cattle slaughtered (ANUALPEC, 2014).

The diet of confined animals is based on the use of concentrates and silages. Alternatives are desirable to replace the roughage in the cattle feed in feedlot to reduce operational costs as well as possible weather-related problems and promote the intensification of the production chain of beef cattle. There is a possibility of using high grain diets that facilitate the supply management, as these diets eliminate the need to produce roughage and subsequently withdraw silage and utilize the advantage of times when cereals have low market value.

In Brazil, there has been an increase of close to $60 \%$ in the production of corn (Zea mays L.) in past 5 years. As a consequence, an increase in the availability of products in the industry has been observed (CONAB, 2014). Therefore, corn is the main energy source used in the production of confined cattle feed; however, other cereals available in the market may be used in animal feed. In addition to crops such as corn, for which Brazil is the third largest producer in the world with approximately 81 million tons, rice (Oryza sativa) is produced on a large scale in the Southern region of Brazil, with an estimated production of 12.5 million tons. Rio Grande do Sul is the largest national producer responsible for approximately $66 \%$ of the national production (CONAB, 2014). In addition, white oat (Avena sativa L.) is a regional crop favored by climatic conditions of the state.

The intensification of beef cattle production has led to the reduction in the age of slaughtered calves and increased the selection pressure, thereby directing females discarded from reproduction to culling. Paulino et al. (2008) stresses that the manipulation of diet and the use of animals from different sex conditions are tools available to the rancher to obtain better economic and productive response. Thus, one must use animals that exhibit good biological response during the finishing period 
that may be met, in part, through the study of noncarcass bovine components such as the evaluation of fat tissue deposition and development of the digestive tract compartments.

According to Owens et al. (1995), the determination of the relative size of the internal organs is important, as differences in the noncarcass components may induce variations in the maintenance of energy requirements. Thus, the objective of this study was to evaluate the characteristics of non-carcass components of steers and heifers finished in feedlot and fed with high grain diets.

\section{MATERIAL AND METHODS}

The present study was approved by the Committee of Ethics for the Use of Animals of the Federal University of Santa Maria (UFSM) under protocol number 145/2014. The experiment was carried out from July to October at the Laboratory of Beef Cattle (LBC) in the Department of Animal Science of UFSM. The climate of the region is subtropical with hot and humid summer, according to the Köppen classification (ALVARES et al., 2013).

A total of 45 cattle of the following two categories of cross between Charolais and Nellore breeds (65\% Charolais 35\% Nellore or $65 \%$ Nellore
35\% Charolais) were used: 21 heifers with initial mean age and weight of 32 months and $359.9 \mathrm{~kg}$, respectively, and 24 steers with initial mean age and weight of 20 months and $337.6 \mathrm{~kg}$. Before the experimental period, the animals were adapted to the facilities, management, and experimental diet for a period of 21 days. During this period, the animals received diets with different roughage: concentrate ratio as follows: concentrate ratios of 50:50, 40:50, and 30:70 for 2 days each; 20:80 and 10:90 for 3 days each; and 0:100 for 10 days. Endoparasite control was performed with subcutaneous application of albendazole-based product (1\% concentration) at a dosage recommended by the manufacturer.

The animals were distributed in the treatment groups balanced by weight and breed predominance and according to the energy source used in the diet comprising whole grains and with husk of: rice, white oat, or corn. Seven heifers and eight steers were included in each group. Animals were placed individually in paved and semi-covered bays and provided with individual feeders for food and water drinkers with water ad libitum, regulated with a float faucet, common to two bays. During the experimental period, animals received isonitrogenous diets according to the formulation presented in Table 1 and in accordance with the respective treatment.

Table 1. Percentage composition and bromatological analysis of the diets

\begin{tabular}{|c|c|c|c|}
\hline \multirow{2}{*}{ Ingredient, $\%$} & \multicolumn{3}{|c|}{ High grain diet } \\
\hline & Rice & White Oat & Corn \\
\hline Corn & - & - & 83.5 \\
\hline White Oat & - & 84.0 & - \\
\hline Rice & 83.4 & - & - \\
\hline Urea & 0.9 & - & 0.5 \\
\hline Limestone calcium & 0.7 & 1.0 & 1.0 \\
\hline Commercial meal & 15.0 & 15.0 & 15.0 \\
\hline \multicolumn{4}{|c|}{ Bromatological composition of the diet, \% } \\
\hline Dry matter & 89.14 & 90.62 & 89.77 \\
\hline Crude protein & 14.20 & 14.97 & 14.17 \\
\hline Ether extract & 1.89 & 4.35 & 3.78 \\
\hline Neutral detergent fiber & 22.43 & 31.05 & 15.93 \\
\hline Acid detergent fiber & 17.76 & 15.25 & 5.28 \\
\hline Lignin & 5.79 & 3.77 & 1.36 \\
\hline Silica & 2.21 & 0.63 & 0.40 \\
\hline Ash & 9.92 & 7.64 & 5.20 \\
\hline Total digestible nutrients & 66.60 & 72.42 & 81.64 \\
\hline Total carbohydrates & 73.99 & 72.92 & 76.84 \\
\hline Non-structural carbohydrates & 55.38 & 43.85 & 63.61 \\
\hline Calcium & 0.78 & 0.88 & 0.95 \\
\hline Phosphorus & 0.39 & 0.49 & 0.40 \\
\hline
\end{tabular}


The commercial meal comprised $32 \%$ crude protein, $12 \%$ humidity, $11 \%$ non-protein nitrogen equivalent in protein, $1.5 \%$ ether extract, and $15 \%$ fibrous material in addition to the minerals calcium, phosphorus, sodium, copper, iron, iodine, selenium, manganese, cobalt, zinc, fluorine, vitamins (A, D3, and E) and antibacterial ionophores lasalocid and virginiamycin. The content of total digestible nutrients was estimated according to Weiss et al. (1992).

The animals were fed ad libitum twice a day, in the morning at 8 o'clock and in the afternoon at 2 o'clock. Before the first feeding, the leftovers from the previous day were collected, which were pre-established between 50 and $80 \mathrm{~g} / \mathrm{kg}$ of the feed offered. The animals were weighed at the beginning of the experimental period and at average intervals of 28 days until the time of shipment to the slaughterhouse. Before being weighed, animals were previously fasted for solids and liquids for 14 h (PACHECO et al., 2013). The time of slaughter was predetermined when the animals reached, by estimate, a warm carcass weight of $220 \mathrm{~kg}$. This weight was stipulated starting from the premise of carcass yields close to $55 \%$, based on studies previously performed by LBC with high grain diet and using animals from the same herd and same breed that presented yields between 55\% and 58\%. The cattle were transported to the commercial slaughterhouse and slaughtering was performed according to the Regulation of Industrial and Sanitary Inspection of Products of Animal Origin (BRASIL, 1952), as per the routine in the slaughter line of the establishment.

During slaughter, all parts of the animal's body were separated and individually weighed; these comprised a set of external components such as the head, feet, ears, horns (when present), tail tip, and hide; vital organs such as lung, liver, kidneys, heart, and spleen; internal fats, including trim fat, inguinal fat, kidney fat, heart fat, ruminal fat, abomasum fat, and intestinal fat; empty gastrointestinal tract such as rumen + reticulum, omasum, abomasum, and intestines (large + small); and blood. Before being sent to the refrigerator, the two half carcasses were identified and weighed to obtain the warm carcass weight and weighed again after $24 \mathrm{~h}$ of cooling to obtain the cold carcass weight. The empty body weight (EBW) was obtained by summing the warm carcass weight, blood, and all sets of grouped components as mentioned above. The weight of the contents of the gastrointestinal tract was obtained from the difference between the slaughter weight and empty body weight.
The experimental design was a completely randomized design with a $3 \times 2$ factorial arrangement (three dietary treatments and two bovine categories). The data were submitted to the analysis of variance by the general linear model (GLM) procedure using the following mathematical model:

$$
\mathrm{Yij}=\mu+\mathrm{Ki}+\mathrm{Tj}+(\mathrm{K} \times \mathrm{T}) \mathrm{ij}+\varepsilon \mathrm{ij}
$$

where, Yij represents the dependent variables; $\mu$ is the general mean of observations; $\mathrm{Ki}$ is the effect of the $\mathrm{i}$-th bovine category; $\mathrm{Tj}$ is the effect of the $\mathrm{j}$-th food treatment; $(\mathrm{K} \times \mathrm{T}) \mathrm{ij}$ is the interaction between the i-th category and the $j$-th food treatment; and eij is the random residual error. The means were compared using an $F$-test and the parameters for which there was a significant effect of food treatment and interactions between categories and food treatment were compared using a Student's $t$-test, at $\alpha=0.05$. The dependent variables were assessed for correlation using Pearson's correlation analysis (proc CORR). The variables were tested for normality by Shapiro-Wilk test using transformation when necessary. All analyses were performed using the SAS statistical package (Statistical Analysis System, version 9.2).

\section{RESULTS AND DISCUSSION}

The slaughter weight differed among the diet groups (Table 2). Animals fed with white oat or corn were heavier than those fed with rice and showed higher average daily weight gain (ARGENTA, 2015). This result was reflected on empty body weight of the animals; the correlation between the slaughter weight and empty body weight was $0.94(\mathrm{P}<0.0001)$. The high correlation between the slaughter weight and empty body weight was previously described by Pacheco et al. (2013). Another aspect that influenced lower empty body weight in animals fed with rice was the lower warm carcass weight (CATTELAM et al., 2018), which contributed the most to the sum of empty body weight; the correlation between these two variables was $0.97 \quad(\mathrm{P}<0.0001)$. The lower performance of the animals fed with rice may be related to the lower energy intake from this diet, thereby resulting in lower slaughter and empty body weight as compared to animals fed with corn or white oat. 
Table 2. Slaughter weight (SW) and empty body weight (EBW), EBW and SW ratio, content of the digestive tract, and warm and cold carcass yields in relation to EBW of steers and heifers finished with high grain diet

\begin{tabular}{|c|c|c|c|c|c|c|c|c|c|c|c|c|c|c|c|c|c|}
\hline \multirow[b]{2}{*}{ Parameters } & \multicolumn{3}{|l|}{ Steer } & \multicolumn{3}{|l|}{ Heifer } & \multirow[b]{2}{*}{ SEM } & \multicolumn{3}{|l|}{ Diet } & \multirow[b]{2}{*}{ SEM } & \multicolumn{2}{|c|}{ Category } & \multirow[b]{2}{*}{ SEM } & \multicolumn{3}{|l|}{$\mathrm{P}$ value } \\
\hline & Rice & $\begin{array}{l}\text { White } \\
\text { Oat }\end{array}$ & Corn & Rice & $\begin{array}{l}\text { White } \\
\text { Oat }\end{array}$ & Corn & & Rice & $\begin{array}{l}\text { White } \\
\text { Oat }\end{array}$ & Corn & & Steer & Heifer & & Diet & Category & $\begin{array}{l}\text { Diet* } \\
\text { Category }\end{array}$ \\
\hline $\begin{array}{l}\text { Slaughter } \\
\text { weight, kg }\end{array}$ & 404.3 & 445.8 & 421.9 & 399.2 & 452.8 & 438.8 & 13.2 & $401.8^{b}$ & $449.3^{\mathrm{a}}$ & $430.4^{\mathrm{a}}$ & 9.4 & 424.1 & 430.2 & 7.63 & 0.037 & 0.5715 & 0.7117 \\
\hline $\begin{array}{l}\text { Empty body } \\
\text { weight, kg }\end{array}$ & 345.2 & 378.4 & 374.1 & 336.8 & 378.4 & 384.1 & 10.0 & $341.0^{\mathrm{b}}$ & $378.0^{\mathrm{a}}$ & $379.1^{\mathrm{a}}$ & 7.37 & 365.9 & 366.2 & 6.21 & 0.008 & 0.9746 & 0.6781 \\
\hline $\begin{array}{l}\text { Digestive tract } \\
\text { content, } \mathrm{kg}\end{array}$ & 59.1 & 67.5 & 47.8 & 62.4 & 75.1 & 54.7 & 4.45 & $60.7^{\mathrm{b}}$ & $71.3^{\mathrm{a}}$ & $51.2^{\mathrm{c}}$ & 3.26 & 58.1 & 64.1 & 2.57 & 0.0004 & 0.1233 & 0.8779 \\
\hline EBW/SW,\% & 85.4 & 84.8 & 88.7 & 84.4 & 83.4 & 87.8 & 0.78 & $84.9^{\mathrm{b}}$ & $84.1^{\mathrm{b}}$ & $88.3^{\mathrm{a}}$ & 0.56 & 86.3 & 85.2 & 0.46 & $<0.001$ & 0.1055 & 0.9182 \\
\hline $\begin{array}{l}\text { Warm carcass } \\
\text { yield }\end{array}$ & 66.6 & 65.5 & 65.8 & 67.0 & 65.9 & 67.1 & 0.56 & 66.8 & 65.7 & 66.5 & 0.40 & 66.0 & 66.7 & 0.32 & 0.1477 & 0.1360 & 0.6500 \\
\hline $\begin{array}{l}\text { Cold carcass } \\
\text { yield }\end{array}$ & 64.8 & 63.9 & 64.4 & 65.7 & 64.4 & 65.3 & 0.56 & 65.3 & 64.2 & 64.9 & 0.40 & 64.4 & 65.1 & 0.33 & 0.1702 & 0.1156 & 0.9074 \\
\hline
\end{tabular}

${ }_{\mathrm{a}, \mathrm{b}, \mathrm{c}}$ Means followed by different letters in the row for the same characteristic differ by the $t$-test $(\mathrm{P}<0.05)$ 
The highest ratio of empty body weight and slaughter weight was observed in animals fed with corn $(88.3 \%)$ as compared to animals fed with rice $(84.9 \%)$ or white oat $(84.1 \%)$. This higher ratio in bovines fed with corn compared to those fed with white oat may be associated with the lower content of the gastrointestinal tract of these animals, higher rate of passage, and lower content of the neutral detergent fiber present in this diet (Table 1). The values observed for the ratio of empty body weight and slaughter weight were close to those reported by NRC (2000) (values of $85 \%$ to 95\%) and the variations may be related to the diet, age, sex, and genetics. Warm and cold carcass yields in relation to empty body weight were unaffected by diets, and the lower carcass weight of animals fed with rice was accompanied with lower slaughter weight, thereby leading to similar yields.

No difference was observed in the variables expressed in Table 2 when evaluated according to the animal category. The similarity in empty body weight was associated with equal slaughter weight owing to the high correlation between these variables as discussed earlier, which reflected the similar empty body weight and slaughter weight ratios; the average value was $85.7 \%$. Paulino et al. (2008) observed similar empty body weight of steers and heifers finished in feedlot. Pacheco et al. (2013) studied the characteristics of the non-carcass components of cattle from different categories finished in feedlot and observed similar empty body weight and slaughter weights, with values of $90.4 \%$ and $87.1 \%$ for steers and heifers, respectively. The carcass yields were similar between the categories evaluated, consistent with the results observed by Cattelan et al. (2010). Although an increase in the fat disposal was observed in heifers (Table 3), the greater participation of peripheral components in the steers resulted in similar carcass yields. The evaluation of carcass yields in relation to empty body weight is of great value mainly in the cold storage industries, as it eliminates the effect of filling the gastrointestinal tract promoted by different types of diets used in the finishing of bovines, thereby facilitating the comparison of carcass characteristics of animals from different production systems and fed with different types of feed and diets with different compositions.

When expressed in relation to empty body weight, the weight of the feet (Table 3) was higher in cattle fed with rice $(2.28 \%)$ as compared to animals fed with corn (2.10\%), with an intermediate value reported in animals fed with white oat
(2.19\%). Assessment of peripheral components based on the animal category revealed the difference in feet weight, with mean values of $2.33 \%$ and $2.06 \%$ for steers and heifers, respectively. Higher relative weight of feet was reported for steers compared with cull cows by Cattelan et al. (2010), wherein steers had 23.5\% higher feet weight adjusted to empty body weight; the authors associated this difference with the early development of these constituents. According to Vaz et al. (2010) the feet are important for the slaughter industry because of the tendons, which are exported to Asian markets.

Other peripheral components were unaltered by diet or animal category evaluated. The head represented $3.57 \%$ of the empty bovine body weight. Similar head weights in cattle of different ages or those fed with different grains were reported by Pazdiora et al. (2009) and Almeida Júnior et al. (2008), respectively. The head is boned and the meat is intended mainly for the production and marketing of minced meat, sausages, and processed foods.

The hide is the peripheral component that shows highest contribution to empty body weight of bovines. In the present study, the hide represented on an average of $9.47 \%$ of empty body weight. Leather is one of the slaughter by-products of greatest interest to slaughterhouses, given the value that can be added after processing mainly by footwear and clothing industries. Green leather represents an important part of the total revenue of the slaughter industry with the commercialization of non-carcass products, highlighting the importance of this component. Similar relative weights of leather in cattle of different ages were reported by Pazdiora et al. (2009) and Cattelan et al. (2010).

The analysis of weights of internal organs showed interaction between the diet and animal category for heart as well as liver. Organ weights of steers fed with corn grain were higher than those of animals from other categories and diets. According to Van Soest (1994), the liver is responsible for the uptake of approximately $80 \%$ of propionate, which passes through the portal system for its conversion to glucose. In addition, the liver is involved in the uptake of ammonia and its conversion into urea. Thus, the reduction in the energy level in the rice diet may have caused lesser development of the liver. Gesualdi Júnior et al. (2001) observed a linear increase in the relative weight of the liver with an increase in the fraction of concentrate in diets of feedlot cattle. 
Table 3. Group of components in relation to the empty body weight (\%) of steers and heifers finished with high grain diets

\begin{tabular}{|c|c|c|c|c|c|c|c|c|c|c|c|c|c|c|c|c|c|}
\hline \multirow[b]{2}{*}{ Parameters, \% } & \multicolumn{3}{|l|}{ Steer } & \multicolumn{3}{|c|}{ Heifer } & \multirow[b]{2}{*}{ SEM } & \multicolumn{3}{|l|}{ Diet } & \multirow[b]{2}{*}{ SEM } & \multicolumn{2}{|c|}{ Category } & \multirow{2}{*}{ SEM } & \multicolumn{3}{|l|}{$\mathrm{P}$ value } \\
\hline & Rice & $\begin{array}{l}\text { White } \\
\text { Oat }\end{array}$ & Corn & Rice & $\begin{array}{l}\text { White } \\
\text { Oat }\end{array}$ & Corn & & Rice & $\begin{array}{l}\text { White } \\
\text { Oat }\end{array}$ & Corn & & Steer & Heifer & & Diet & Category & $\begin{array}{l}\text { Diet* } \\
\text { Category }\end{array}$ \\
\hline \multicolumn{18}{|l|}{ Peripheral components } \\
\hline Ears & 0.25 & 0.23 & 0.27 & 0.25 & 0.23 & 0.23 & 0.01 & 0.25 & 0.23 & 0.25 & 0.01 & 0.25 & 0.24 & 0.09 & 0.3005 & 0.4069 & 0.2492 \\
\hline Head & 3.75 & 3.54 & 3.48 & 3.73 & 3.58 & 3.34 & 0.08 & 3.73 & 3.56 & 3.41 & 0.05 & 3.59 & 3.55 & 0.02 & 0.007 & 0.5082 & 0.5124 \\
\hline Feet & 2.47 & 2.28 & 2.24 & 2.10 & 2.10 & 1.96 & 0.06 & $2.28^{\mathrm{a}}$ & $2.19^{\mathrm{ab}}$ & $2.10^{\mathrm{b}}$ & 0.04 & $2.33^{\mathrm{A}}$ & $2.06^{\mathrm{B}}$ & 0.04 & 0.0207 & $<0.0001$ & 0.3438 \\
\hline Tail tip & 0.03 & 0.03 & 0.04 & 0.05 & 0.03 & 0.02 & 0.01 & 0.05 & 0.03 & 0.04 & 0.01 & 0.04 & 0.04 & 0.01 & 0.5017 & 0.9495 & 0.1593 \\
\hline Hide & 10.1 & 9.59 & 8.90 & 9.74 & 9.01 & 8.90 & 0.41 & 9.90 & 9.30 & 9.20 & 0.30 & 9.72 & 9.22 & 0.24 & 0.1974 & 0.1569 & 0.9002 \\
\hline Total & 16.6 & 15.7 & 15.5 & 15.9 & 14.9 & 14.5 & 0.46 & $16.2^{\mathrm{a}}$ & $15.3^{\mathrm{ab}}$ & $15.0^{\mathrm{b}}$ & 0.33 & $15.9^{\mathrm{A}}$ & $15.1^{\mathrm{B}}$ & 0.27 & 0.0301 & 0.0340 & 0.8762 \\
\hline \multicolumn{18}{|l|}{ Internal organs } \\
\hline Heart & $0.33^{\beta}$ & $0.34^{\beta}$ & $0.37^{\alpha}$ & $0.33^{\beta}$ & $0.33^{\beta}$ & $0.33^{\beta}$ & 0.01 & $0.33^{\mathrm{b}}$ & $0.35^{\mathrm{a}}$ & $0.34^{\mathrm{a}}$ & 0.01 & $0.34^{\mathrm{A}}$ & $0.33^{\mathrm{B}}$ & 0.01 & 0.0183 & 0.0339 & 0.0407 \\
\hline Lungs & $1.35^{\alpha}$ & $1.40^{\alpha}$ & $1.37^{\alpha}$ & $1.36^{\alpha}$ & $1.20^{\beta}$ & $1.18^{\beta}$ & 0.04 & 1.36 & 1.30 & 1.27 & 0.03 & $1.37^{\mathrm{A}}$ & $1.25^{\mathrm{B}}$ & 0.02 & 0.1570 & 0.0009 & 0.0246 \\
\hline Liver & $1.28^{\beta}$ & $1.33^{\beta}$ & $1.57^{\alpha}$ & $1.08^{\gamma}$ & $1.22^{\beta}$ & $1.23^{\beta}$ & 0.04 & $1.18^{\mathrm{c}}$ & $1.27^{\mathrm{b}}$ & $1.40^{\mathrm{a}}$ & 0.03 & $1.39^{\mathrm{A}}$ & $1.18^{\mathrm{B}}$ & 0.02 & $<0.0001$ & $<0.0001$ & 0.0439 \\
\hline Kidneys & 0.22 & 0.21 & 0.23 & 0.19 & 0.18 & 0.18 & 0.01 & 0.20 & 0.19 & 0.20 & 0.01 & $0.22^{\mathrm{A}}$ & $0.18^{\mathrm{B}}$ & 0.01 & 0.7101 & $<0.0001$ & 0.4042 \\
\hline Spleen & 0.32 & 0.34 & 0.40 & 0.28 & 0.31 & 0.30 & 0.02 & 0.30 & 0.32 & 0.35 & 0.01 & $0.35^{\mathrm{A}}$ & $0.29^{\mathrm{B}}$ & 0.01 & 0.0856 & 0.0006 & 0.1898 \\
\hline Total & $3.50^{\beta}$ & $3.62^{\beta}$ & $3.88^{\alpha}$ & $3.24^{\gamma}$ & $3.25^{\gamma}$ & $3.22^{\gamma}$ & 0.07 & 3.37 & 3.44 & 3.55 & 0.05 & $3.67^{\mathrm{A}}$ & $3.24^{\mathrm{B}}$ & 0.04 & 0.0542 & $<0.0001$ & 0.0268 \\
\hline \multicolumn{18}{|l|}{ Gastrointestinal tract } \\
\hline Rumen + reticulum & 1.68 & 1.87 & 1.76 & 1.68 & 1.82 & 1.80 & 0.08 & 1.68 & 1.84 & 1.78 & 0.06 & 1.77 & 1.77 & 0.05 & 0.1500 & 0.9876 & 0.8759 \\
\hline Omasum & $0.70^{\beta}$ & $0.70^{\beta}$ & $0.57^{\gamma}$ & $0.98^{\alpha}$ & $0.76^{\beta}$ & $0.51^{\gamma}$ & 0.04 & $0.84^{\mathrm{a}}$ & $0.73^{\mathrm{b}}$ & $0.54^{\mathrm{c}}$ & 0.03 & $0.65^{\mathrm{B}}$ & $0.75^{\mathrm{A}}$ & 0.02 & $<0.0001$ & 0.0066 & 0.0006 \\
\hline Abomasum & 0.35 & 0.50 & 0.32 & 0.39 & 0.60 & 0.30 & 0.03 & $0.37^{\mathrm{b}}$ & $0.55^{\mathrm{a}}$ & $0.31^{\mathrm{c}}$ & 0.03 & 0.39 & 0.43 & 0.02 & $<0.0001$ & 0.5606 & 0.1850 \\
\hline Intestines & 1.72 & 1.67 & 1.87 & 1.59 & 1.60 & 1.60 & 0.10 & 1.66 & 1.63 & 1.73 & 0.08 & 1.75 & 1.60 & 0.06 & 0.8247 & 0.0864 & 0.5009 \\
\hline Total & 4.78 & 5.05 & 4.86 & 5.23 & 5.34 & 4.73 & 0.17 & 5.00 & 5.20 & 4.80 & 0.12 & 4.89 & 5.10 & 0.10 & 0.0990 & 0.1670 & 0.2587 \\
\hline \multicolumn{18}{|l|}{ Discarded fats } \\
\hline Heart & 0.05 & 0.05 & 0.05 & 0.05 & 0.05 & 0.05 & 0.01 & 0.05 & 0.05 & 0.05 & 0.01 & 0.05 & 0.05 & 0.01 & 0.8259 & 0.5098 & 0.9171 \\
\hline Kidney & 0.93 & 1.31 & 1.30 & 1.06 & 1.34 & 1.42 & 0.11 & $0.99^{\mathrm{b}}$ & $1.32^{\mathrm{a}}$ & $1.36^{\mathrm{a}}$ & 0.08 & 1.18 & 1.27 & 0.06 & 0.0086 & 0.3510 & 0.8439 \\
\hline Inguinal & 0.50 & 0.66 & 0.62 & 0.69 & 0.94 & 1.02 & 0.07 & $0.60^{\mathrm{b}}$ & $0.80^{\mathrm{a}}$ & $0.82^{\mathrm{a}}$ & 0.06 & $0.60^{\mathrm{B}}$ & $0.89^{\mathrm{A}}$ & 0.04 & 0.0113 & $<0.0001$ & 0.7469 \\
\hline Rumen & 1.20 & 1.66 & 1.46 & 1.22 & 1.71 & 1.66 & 0.12 & $1.21^{\mathrm{b}}$ & $1.69^{\mathrm{a}}$ & $1.56^{\mathrm{a}}$ & 0.09 & 1.44 & 1.53 & 0.07 & 0.0028 & 0.4253 & 0.7675 \\
\hline Abomasum & 0.42 & 0.59 & 0.49 & 0.43 & 0.61 & 0.53 & 0.05 & $0.43^{\mathrm{b}}$ & $0.60^{\mathrm{a}}$ & $0.51^{\mathrm{a}}$ & 0.03 & 0.50 & 0.53 & 0.03 & 0.0041 & 0.5905 & 0.9591 \\
\hline Intestine & 3.09 & 4.04 & 3.68 & 3.24 & 4.31 & 4.18 & 0.25 & $3.16^{\mathrm{b}}$ & $4.17^{\mathrm{a}}$ & $3.92^{\mathrm{a}}$ & 0.18 & 3.60 & 3.91 & 0.15 & 0.0008 & 0.1493 & 0.7818 \\
\hline Trim & 0.32 & 0.30 & 0.33 & 0.27 & 0.34 & 0.36 & 0.02 & 0.29 & 0.32 & 0.34 & 0.02 & 0.32 & 0.32 & 0.01 & 0.2286 & 0.9335 & 0.2031 \\
\hline Total & 4.89 & 6.37 & 5.98 & 5.32 & 6.98 & 7.04 & 0.38 & $5.10^{\mathrm{b}}$ & $6.68^{\mathrm{a}}$ & $6.51^{\mathrm{a}}$ & 0.27 & $5.75^{\mathrm{B}}$ & $6.45^{\mathrm{A}}$ & 0.22 & 0.0003 & 0.0315 & 0.7066 \\
\hline Blood & 3.60 & 3.62 & 3.90 & 3.29 & 3.52 & 3.38 & 0.17 & 3.45 & 3.57 & 3.64 & 0.11 & $3.71^{\mathrm{A}}$ & $3.39^{\mathrm{B}}$ & 0.10 & 0.4597 & 0.0248 & 0.4648 \\
\hline
\end{tabular}

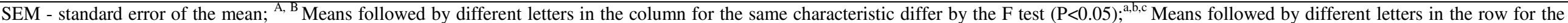
same characteristic differ by the $t$-test $(\mathrm{P}<0.05) ;{ }^{\alpha, \beta}, \gamma$ Means followed by different letters for the same characteristic differ by the $t$-test $(\mathrm{P}<0.05)$ 
The analysis of the internal organs based on the category of cattle studied revealed that the steers had higher weights. This observation may be possibly related to the higher development rate in early stages due to hyperplasia, which is the increase in the number of cells of the tissues that is more intense in the initial stages of the life of the animals (GESUALDI JÚNIOR et al., 2001). The vital organs sustain greater development in earlier phases of the life of the animal and the development decreases with the advancing age. Further development of the internal organs in calves slaughtered within 13.1 months of age compared to 2-year-old calves was reported by Pazdiora et al. (2009). In addition, heifers fed with white oat or corn displayed lower lung weight as compared to those fed with other diets. These changes in the weight and involvement of internal organs, especially heart and lung, differ from those reported by -Gesualdi Júnior et al. (2001) and Véras et al. (2001). These previous reports state that organs such as heart and lung have priorities in the use of nutrients and tend to maintain their integrity, regardless of diet. No change was observed in the relative weights of the spleen with different diet, following the similarity presented for the blood component, possibly due to the association with the function of this component (blood storage); the correlation between blood and these organs was significant and positive $(r=0.59 ; \mathrm{P}<0.0001)$.

A significant interaction between diet and category studied was observed for the weight of the omasum, being that regardless of the sex of the animal, animals fed with rice or white oat showed greater development of omasum. That is evidentied from the lowest content of the gastrointestinal tract for cattle fed with corn (Table 2). According to Van Soest (1994), the omasum reabsorbs water aside from selecting the material that enters the abomasum and retaining the fibrous portion.

The abomasum displayed

greater development in animals fed with white oat as compared rice-fed animals, which showed higher values than cattle fed with corn. The higher development of the abomasum in animals fed with white oat must be related to the greater dietary energy intake and higher fiber content, which possibly reduced its rate of passage and promoted a greater development of this compartment. On the other hand, the corn diet provided higher energy but resulted in a higher rate of passage, thereby reducing the participation of the abomasum and increasing the participation of the intestines in the digestive process. According to Kozloski (2011), diets rich in cereals with high starch content, such as corn, pass quickly through the first compartment of the gastrointestinal tract without being fermented; such diets are digested in the small intestine.

The evaluation of the fat deposits revealed that heart fat was not influenced by the type of feed used in the diet. For the other adipose tissue deposits, animals fed with rice displayed lower values for the different fat deposits in terms of empty body weight, possibly due to dietary energy intake. Although no difference in the consumption of total digestible nutrients was observed (ARGENTA, 2015), the author points out that the laboratory evaluation of the samples involves processing through grinding, which exposes all starch protected by the bark of the grains. Thus, the author considers that ruminal microorganisms of rice-fed animals are unable to degrade all starch present in the grains owing to the high silica and lignin content in the bark, which poses difficulty in the enzymatic degradation and reduces the energy utilization of the diet. Some studies have shown that the use of high ruminal escape starch favors visceral fat deposition by prioritizing intestinal starch digestion (TANIGUCHI et al., 1995).

The evaluation of the inguinal fat revealed that heifers had $48.3 \%$ higher content than steers, the difference being related to the presence of mammary gland (udder) in females. Higher weight of fat from the inguinal region in heifers as compared with steers was reported by $\mathrm{Vaz}$ et al. (2010). The greater deposition of different types of fat in heifers as compared to steers reported by Cattelan et al. (2010) was associated with the more advanced stage of maturity of cows.

The evaluation of all the peripheral components showed that cattle fed with rice exhibited higher weights as compared with the animals fed with corn, with intermediate weight for the animals fed with white oat. This result was accompanied by the variations in the feet weight, the third largest of the peripheral components. The set of peripheral components in relation to empty body weight was higher in steers $(15.9 \mathrm{~kg} / 100 \mathrm{~kg}$ of EBW) as compared to heifers $(15.1 \mathrm{~kg} / 100 \mathrm{~kg}$ of EBW), which may be related to the increase in the development of the feet, as previously mentioned, and to the early development of non-carcass peripheral components. Cattelan et al. (2010) observed a higher ratio of non-carcass peripheral components in steers as compared to cull cows. Kuss et al. (2007) observed that the increase in the slaughter weight of cows resulted in a decrease in non-carcass peripheral components, consistent with the observation of Restle et al. (2005), wherein the components mentioned above had greater 
development momentum during the initial phases with stabilization when the animal reached maturity.

An interaction was observed between the diet and animal category studied for total internal organs, being that for the different diets evaluated, steers presented higher weight than heifers. This observation may be possibly related to the greater weights of different internal organs upon individual evaluation. This hypothesis was confirmed on the evaluation of total internal organs according to the category of cattle, wherein superior values were observed for steers. The greater development of internal organs in younger animals was in agreement with the report of Sisson and Grossman (1986), which stated that the relative participation of the internal organs decreases as the animal matures.

No difference was observed in the total number of components of the gastrointestinal tract between treatment groups and food categories. The total amount of fat deposited by cattle was higher in animals fed with white oat or corn and was associated with the higher deposition of different types of fats upon separate evaluation, owing to the higher energy density of diets. According to Véras et al. (2001), the increase in the energy level of the diet results in the higher deposition of adipose tissue by the animal. According to Owens (1995), the sites of deposition of fat influence the nutritional requirements of animals and the increase in fat deposition raises the maintenance energy requirements because of the increased metabolic activity of the internal adipose tissue (GESUALDI JÚNIOR et al., 2001).
The total amount of fat deposited was different between the categories evaluated, with heifers presenting $13 \%$ more adipose tissue that steers. This difference may be associated with the more advanced stage of development in cows as well as the higher precocity of cows in the deposition of fat tissue. The higher deposition of the adipose tissue in cows as compared to bulls has been reported by Cattelan et al. (2010).

The relative weight of blood was similar for the different diets evaluated, following the development presented in the total of other sets of components as digestive tract and especially of the internal organs, as previously discussed. Among the categories studied, blood weight was higher in steers than heifers. Ribeiro et al. (2001) reported that the increase in blood volume is associated with the growth of vital organs and digestive tract. In the present study, a correlation was observed between blood weight and total of vital organs $(r=0.60$; $\mathrm{P}<0.001)$.

\section{CONCLUSIONS}

The use of high grain diets based on corn or white oat in the finishing of cattle leads to an increase in the development of the gastrointestinal tract, while feed comprising rice grains results in the less deposition of adipose tissue.

Steers exhibit larger development of internal organs, while heifers display greater deposition of fat discarded.

RESUMO: O presente estudo teve por objetivo quantificar as partes não-integrantes da carcaça de novilhos e novilhas, terminados em confinamento alimentados com dietas de alto grão. Utilizaram-se 45 bovinos de duas categorias, sendo 21 novilhas com idade inicial de 32 meses e 24 novilhos com idade inicial de 20 meses, oriundos do cruzamento entre as raças Charolês e Nelore. Os animais receberam dietas de $100 \%$ concentrado e foram distribuídos nos tratamentos conforme a fonte energética utilizada, sendo essas: arroz; aveia branca ou milho, sendo utilizados sete novilhas e oito novilhos para cada dieta alimentar. O delineamento experimental foi o inteiramente casualizado, com arranjo fatorial $3 \times 2$, utilizando $\mathrm{P}<0,05$. Os pesos de abate e de corpo vazio foram superiores nos animais alimentados com milho (430,4 kg e $379,1 \mathrm{~kg}$, respectivamente) ou aveia branca (449,3 kg e 378,0 kg, respectivamente) em relação aos animais que receberam arroz (401,9 kg e 341,0 kg, respectivamente). A exceção da gordura de coração e da gordura abomasal, para os demais depósitos de tecido adiposo, os animais alimentados com arroz apresentaram menores valores. Os novilhos apresentaram maior desenvolvimento dos órgãos internos (3,67\% contra 3,24\%), das patas (2,33\% contra 2,06\%) e total de componentes periféricos $(15,9 \%$ contra $15,1 \%)$, enquanto as novilhas apresentaram maior deposição no total de gorduras $(6,45 \%$ contra $5,75 \%)$, expressos em relação ao peso de corpo vazio. A utilização de dietas de alto grão a base de milho ou aveia branca na terminação de bovinos acarreta maior desenvolvimento de órgãos internos e do trato digestório, enquanto a alimentação com grãos de arroz proporciona menor deposição de tecido adiposo.

PALAVRAS-CHAVE: Arroz. Aveia branca. Gordura. Milho. Peso de corpo vazio. Trato digestivo 


\section{REFERENCES}

ALMEIDA JÚNIOR, G. A.; COSTA, C.; CARVALHO, S. M. R.; PANICHI, A.; PERSICHETTI JÚNIOR, P. Características da carcaça e dos componentes não-carcaça de bezerros holandeses alimentados após o desaleitamento com silagem de grãos úmidos ou grãos secos de milho ou sorgo. Revista Brasileira de Zootecnia, Viçosa, v. 37, p. 157-163, 2008. http://dx.doi.org/10.1590/S1516-35982008000100023

ALVARES, C. A.; STAPE, J. L.; SENTELHAS, P. C.; GONÇALVES, J. L. M.; SPAROVEK, G. Köppen's climate classification map for Brazil. Meteorologische Zeitschrift, Stuttgart, v. 22, n. 6, p. 711-728, 2013. http://dx.doi.org/10.1127/0941-2948/2013/0507

ANUALPEC. Anuário da pecuária brasileira. 2014. São Paulo: AgraFNP. 313p.

ARGENTA, F. M. Grãos inteiros de milho, aveia branca ou arroz com casca na terminação de bovinos confinados - desempenho e comportamento ingestivo. 2015. 96f. Tese (Doutorado em Zootecnia) Programa de Pós-Graduação em Zootecnia, Universidade Federal de Santa Maria, Santa Maria, 2015.

BRASIL. Decreto no 30691, de 29/03/52. RIISPOA - Regulamento da Inspeção Industrial e Sanitária de Produtos de Origem Animal. Brasília/DF. 1952. Disponível em:

$<$ http://www2.camara.leg.br/legin/fed/decret/1950-1959/decreto-30691-29-marco-1952-339586normaatualizada-pe.pdf> Acesso em 23 nov. 2014.

CATTELAN, J.; MENEZES, L. F. G.; FERREIRA, J. J.; RESTLE, J.; ALVES FILHO, D. C.; BRONDANI, I. L. Gorduras de descarte e componentes externos do corpo de novilhos e vacas de descarte de diferentes grupos genéticos. Ciência Rural, Santa Maria, v. 40, n. 12, p. 2541-2548, 2010. http://dx.doi.org/10.1590/S010384782010001200017

CATTELAM, J.; ARGENTA, F. M.; ALVES FILHO, D. C.; BRONDANI, I. L.; PACHECO, P. S.;

PACHECO, R. F., MAYER, A. R.; RODRIGUES, L. S.; MARTINI, P. M.; KLEIN, J. L. Characteristics of the carcass and quality of meat of male and female calves with different high-grain diets in confinement. Semina:

Ciências Agrárias, Londrina, 2018 (No prelo)

COMPANHIA NACIONAL DE ABASTECIMENTO - CONAB. Acompanhamento da safra brasileira: Grãos. v.1 Safra 2013/ 2014. CONAB: Brasília. 2014. 127p. Disponível em:

$<$ http://www.conab.gov.br/OlalaCMS/uploads/arquivos/14_09_10_14_35_09_boletim_graos_setembro_2014.p df> Acesso em: 23 nov. 2014.

GESUALDI JÚNIOR, R. A., VELOSO, C. M.; PAULINO, M. F; VALADARES FILHO, S. C.; GESUALDI, A. C. L. S.; CECON, P. R. Níveis de concentrado na dieta de bovinos F1 Limousin x Nelore: peso dos órgãos internos e trato digestivo. Revista Brasileira de Zootecnia, Viçosa, v. 30, n. 6, p. 1866-1971, 2001. http://dx.doi.org/10.1590/S1516-35982001000700024

KOZLOSKI, Gilberto Vilmar. Bioquímica de ruminantes. 3 ed. Editora UFSM. Santa Maria. 2011. 216p.

KUSS, F.; RESTLE, J.; BRONDANI, I. L.; PASCOAL, L. L.; MENEZES, L. F. G.; LEITE, D. T.; SANTOS, M. F. Componentes externos do corpo e gordura de descarte em vacas mestiças Charolês x Nelore abatidas com diferentes pesos. Revista Brasileira de Zootecnia, Viçosa, v. 36, n. 4, p. 865-873, 2007.

http://dx.doi.org/10.1590/S1516-35982007000400016

NRC - National research council. Nutrient requirements of beef cattle. 7th ed. National Academy Press, Washington, D.C. 2000. 242 p.

OWENS, F. N.; GILL, D. R.; SECRIST, D. S.; COLEMAN, S. W. Review of some aspects of growth and development of feedlot cattle. Journal of Animal Science, Champaign, v. 73, p. 3152-3172, 1995.

http://dx.doi.org /10.2527/1995.73103152x 
PAULINO, P. V. R.; VALADARES FILHO, S. C.; DETMANN, E.; VALADARES, R. F. D.; FONSECA, M. A.; VÉRAS, R. M. L.; OLIVEIRA, D. M. Desempenho produtivo de bovinos Nelore de diferentes classes sexuais alimentados com dietas contendo dois níveis de oferta de concentrado. Revista Brasileira de Zootecnia, Viçosa, v. 37, n. 6, p. 1079-1087, 2008. http://dx.doi.org/10.1590/S1516-35982008000600019

PACHECO, P. S.; RESTLE, J.; MISSIO, R. L.; MENEZES, L. F. G.; ROSA, J. R. P.; KUSS, F.; ALVES FILHO, D. C.; NEIVA, J. N. M.; DONICHT, P. A. M. M. Características da carcaça e do corpo vazio de bovinos Charolês de diferentes categorias abatidos com similar grau de acabamento. Arquivo Brasileiro de Medicina Veterinária e Zootecnia, Belo Horizonte, v. 65, n. 1, p. 281-288, 2013. http://dx.doi.org/10.1590/S0102-09352013000100040

PAZDIORA, R. D.; SANTOS, A. P.; BRONDANI, I. L.; RESTLE, J.; ARBOITTE, M. Z.; CEZIMBRA, I. M. Componentes não-integrantes da carcaça de novilhos jovens e superjovens terminados em confinamento. Acta Scientarum. Animal Science, Maringá, v. 30, n. 1, p. 95-101, 2009. http://dx.doi.org/10.4025/actascianimsci.v31i1.542

RESTLE, J.; MENEZES, L. F. G.; ARBOITTE, M. Z.; PASCOAL, L. L.; PACHECO, P. S.; PÁDUA, J. T. Características das partes não-integrantes da carcaça de novilhos 5/8 Nelore 3/8 Charolês abatidos em três estádios de desenvolvimento. Revista Brasileira de Zootecnia, Viçosa, v. 34, n. 4, p. 1339-1348, 2005. http://dx.doi.org/10.1590/S1516-35982005000400031

RIBEIRO, T. R.; PEREIRA, J. C.; LEÃO, M. I.; OLIVEIRA, M. V. M.; QUEIROZ, A. C.; CECON, P. R.; MELO, R. C. A. Tamanho de órgãos e vísceras de bezerros Holandeses, para produção de vitelos recebendo dietas com diferentes níveis de concentrado. Revista Brasileira Zootecnia, Viçosa, v. 30, n. 6, p. 2163-2168, 2001. (Suplemento). http://dx.doi.org/10.1590/S1516-35982001000800027

SAS INSTITUTE. SAS/STAT User's Guide: statistics. 2.ed. Version 9.2, Cary, NC 2009.

SISSON, Septimus; GROSSMAN, James Daniels. Anatomia dos animais domésticos. 5.ed. Rio de Janeiro: Guanabara Koogan, 1986. v.1, 1134p.

TANIGUCHI, K.; HUNTINGTON, G.B.; GLENN, B.P. Net nutrient flux by visceral tissues of beef steers given abomasal and ruminal infusions of casein and starch. Journal of Animal Science, Champaign, v. 73, n. 1, p. 236-249, 1995. http://dx.doi.org/10.2527/1995.731236x

VAN SOEST, Peter J. Nutritional ecology of ruminant. 2.ed. London: Constock Publishing Associates, 1994. $467 \mathrm{p}$.

VAZ, F. N.; RESTLE, J.; ARBOITTE, M. Z.; PASCOAL, L. L.; FATURI, C.; JONER, G. Fatores relacionados ao rendimento de carcaça de novilhos ou novilhas superjovens, terminados em pastagem cultivada. Ciência Animal Brasileira, Goiânia, v. 11, n. 1, p. 53-61, 2010.

http://dx.doi.org/10.5216/cab.v11i1.6747

VÉRAS, A. S. C.; VALADARES FILHO, S. C.; SILVA, J. F. C.; PAULINO, M. F.; CECON, P. R.; VALADARES, R. F. D.; FERREIRA, M. A.; FONTES, C. M. S. Efeito do nível de concentrado sobre o peso dos órgãos internos e do conteúdo gastrintestinal de bovino Nelore não-castrados. Revista Brasileira de Zootecnia, Viçosa, v. 30, n. 3, p. 1120-1126, 2001. http://dx.doi.org/10.1590/S1516-35982001000400029

WEISS, W. P.; CONRAD, H. R.; PIERRE, N. R. A theoretically-based model for predicting total digestible nutrient values of forages and concentrates. Animal Feed Sciene Technology, Amsterdam, v. 39, p. 95-110, 1992. https://doi.org/10.1016/0377-8401(92)90034-4 